\begin{tabular}{|c|c|}
\hline \multirow{3}{*}{ 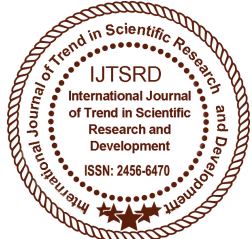 } & International Journal of Trend in Scientific Research and Development (IJTSRD) \\
\hline & International Open Access Journal | www.ijtsrd.com \\
\hline & ISSN No: 2456 - 6470 | Volume - 2 | Issue - 6 | Sep - Oct 2018 \\
\hline
\end{tabular}

\title{
A Review on Herbs with Esterogenic Activity
}

\author{
G. Rathiga ${ }^{1}$, M. Mohammed Fharook ${ }^{2}$ \\ ${ }^{1}$ PG Scholar, Department of Maruthuvam, Institute of Siddha, Chennai, Tamil Nadu, India \\ ${ }^{2}$ PG Scholar, Department of Gunapadam, Government Siddha Medical College, Chennai, Tamil Nadu, India
}

\begin{abstract}
60 million women in India all above the age of 55 years, with women living longer than before, a majority would spend $1 / 3$ of their life in the postmenopausal stages. The health problems cropping up during this period and related to estrogen deficiency of menopause are several decades to identify effective and safe substances for estrogen regulation. This approach proved to be a good alternative to synthetic drugs as the chemicals of plant origin have limited side effects. Various medicinal plants extracts were investigated for their estrogenic activity in animal models. This review presents update information gathered on scientifically screened medicinal plants used for estrogenic activity in females. This review provides the information on botanical name along with their family, parts used, chemical constituents and their estrogenic activity on target organ.
\end{abstract}

Keywords: Estrogenic activity, menopause, medicinal plants, hormone replacement therapy.

INTRODUCTION

Estrogen is naturally occur hormones and are of importance both for female and male gender. It regulates growth and differentiation of cells, decrease apoptosis and regulate growth factor production. Estrogen play important role only in reproduction system but in functioning of cardiovascular, central nervous, immune and skeletal system. ${ }^{[1]} 66 \%$ reduction in estrogen at menopause. Menopause with chronic estrogen deficiency are liable to develop the following: osteoporosis and fracture, ischemic heart disease, myocardial infarction, atherosclerosis, hypertension, stroke, tooth decay, cataract, glaucoma. [2]

The common therapy given to supply the needs of estrogen is by the hormone replacement therapy(HRT), the hormone used on HRT facilitates the physiological regulation that the natural estrogen dose, but based on the several researchers HRT gives the risk in the stimulation of carcinogenesis process, lead to the enhancement of breast cancer, stroke and blood coagulation. Therefore the alternative therapy for HRT that is safer and affordable for the society should be developed ${ }^{[3]}$

Table: List of studied for estrogenic activity:

\begin{tabular}{|c|c|c|c|}
\hline S. No & Botanical name & Family & Parts used \\
\hline 1. & Pimpinellaanisum. L & Umbelliferae & Seed \\
\hline 2. & Ricinuscommunis. L & Euphorbiaceae & Seed \\
\hline 3. & Glycyrrhizaglabra. L & Fabaceae & Root \\
\hline 4. & Musa paradisiaca. L & Musaceae & Stem \\
\hline 5. & Erythrinavarigata. L & Fabaceae & Leaf \\
\hline 6. & Aloe vera. L & Aspodelaceae & Leaf (sap) \\
\hline 7. & Bauhinia racemosa. Lam & Fabaceae & Stem bark \\
\hline 8. & Asparacusracemosus. Willd & Liliaceae & Root tuber \\
\hline 9. & Nigella sativa. L & Ranunculacae & Seed \\
\hline 10. & Punicagranatum.L & Lythracae & Fruit \\
\hline 11. & Saracaasoca.Willd & Fabaceae & Flower \\
\hline 12. & Caricapapaya.L & Caricaceae & Leaf \\
\hline
\end{tabular}


International Journal of Trend in Scientific Research and Development (IJTSRD) ISSN: 2456-6470

\begin{tabular}{|c|c|c|c|}
\hline 13. & Glycine max.L & Fabaceae & Seed \\
\hline 14. & Cissusquadrangularis.L & Vitacae & Whole plant \\
\hline 15. & Bambusaarundinaceae.Willd & Poacaeae & Leaf \\
\hline
\end{tabular}

Pimpinellaanisum. L (Aniseed):

Chemical contituents: Euginol, Trans anethol, methylchavicol, anisaldehyde, estragole, coumarins, scopletin, umbelliferone, polypenes, polyacetelenes, (E)-methyleugenol, $\alpha$-cuparene, $\alpha$-himachalene, $\beta$ bisabolene, p-anisaldehyde, cis-anethol. ${ }^{[4,5]}$

1. The extract was found to be active in stimulating the differentiating andminerlisation of osteoblastic cell culture and inducing like antiestrogens, the insulin growth factor binding protein 3 in mcf-7 Breast cancer cells. No effect was observed on the proliferation of cervical adenocarcinoma cells using the MTT assay the presence of estradiol inhibition the anti-estrogenic effect, thus suggesting as estrogen receptor related mechanism [6]

2. Transanethol administered orally to immature female rats at $80 \mathrm{mg} / \mathrm{kg}$ body weight for 3 days. Significantly increased uterine weight to $2 \mathrm{mg} / \mathrm{kg}$ compared to $0.5 \mathrm{~g} / \mathrm{kg}$ in controls. The results confirmed that trans anethol has estrogenic activity. [7]

3. Anis is used in the development of synthetic estrogen where the main constituents of plant oil anethol has been considered as the active estrogenic agent. ${ }^{[8]}$

4. Anethol from the plant oil has been used for alleviation of menopausal symptoms, prevention of osteoporosis, heart disease and cancer. ${ }^{[9]}$

5. P.anisum may have more preference than the other herbs or chemical drugs due to the treatment with P.anisum and placebo to determine maintancep. anisum effects an menopausal hot flashes. The results showed that p.anisum can control the symptoms long after the consumption. ${ }^{[10]}$

6. The essential oils containing (E)-anethol as major compound showed estrogenic activity in the YES assay. This study indicates that the estrogenic activity of pimpinella oils is not solely due to the presence of anethol components other than anethol may be responsible for contributing towards the estrogenic activity. ${ }^{[1]}$

Ricinuscommunis. L (Castor bean):

Chemical constituents: Alkaloids, ricinoleic acid, stearic, linoleic, palmiticacid, sitosterol, squalene, tocopherol, flavonoids, benzoic acid derivatives, coumarin, terpenoids, fatty acid, ricinine, isorecinoic acid $[12,13,14]$

1. The ether soluble portion of the menthanol extract of R.communis var. minor possesses antiimplantionanti conceptive and estrogenic activity in adult female rats and rabbits when administered subcutaneously at a dose upto $1.2 \mathrm{~g} / \mathrm{kg}$ and $600 \mathrm{mg} / \mathrm{kg}$ respectively in divided dose. $^{[15]}$

2. In this study 27 female albino rats were used in the determination of aqueous suspension of R.communis seed. Estrogen and progestine levels of these rats were analyzed using electrochemiluminescent method. The results revealed estrogenic property of aqueous suspension of R.communis seed which is partly attributed to the anticonceptive effect of the seed $^{[16]}$

3. Pregnant rats exposed to reo in this study also showed significantly reduced serum levels of progestine and estrogens when compared with control. The major estrogen produced during human pregnancy is estriol and elevated estriol levels indicate fetal wellbeing [17]

Glycyrrhizaglabra. L (Liquoice):

Chemical constituents: Liquirrtein, isoliquertin, liquiritigenin, rhamnoliquirilin, prenyllicoflavane A, shinflavone, glycyrrhizine, glycyrrhelic acid, isoliquiritin, glycyrrhetic acid, isoflavones ${ }^{[18,19]}$

1. Glabridin is an isoflavan from licorice root, which is common component of herbal remedies used for treatment of menopausal symptoms. Past studies have been shown that glabridin resulted in favorable outcome similar to $17 \beta$-estradiol suggesting possible role as an estrogen replacement therapy ${ }^{[20]}$

2. Data from both in vivo and in vitro experiments demonstrated that glabridin and glabrine are similar to estradiol -17 beta in their stimulation of the specific activity of creatine, kinase although at higher concentration, but differ in their extent of action and interaction with other drugs. Whereas glabrene was more effective in post menopausal cells ${ }^{[21,22]}$

3. post menopausal women have higher incidence of heart disease compared to premenopausal women suggesting a productive role for estrogen. In the 
present study we tested the effects on vascular tissue in vitro of two natural compounds derived from licorice root glabridin stimulated DNA synthesis in human endothelial cells and had a biphasic effect in proliferation of human vascular smooth muscle ${ }^{[23]}$

Musa paradisiaca. L (Plantain):

Chemical constituents: Alkaloids, tannin, flavonoids, phenol, saponin, oxalates, glycoside, terphenoid, steroid,polyphenol. ${ }^{[24,25,26]}$

1. Ethanolic extract of stem of M.paradisiaca was found to posses significant estrogenic activity as indicated by increase in uterine weight, vaginal cornification and uteritropic response. The stem extract acted as estrogen when given alone but when given with ethinyl estradiol it exhibited slight antiestrogenic activity. ${ }^{[27]}$

\section{Erythrinavariegate. L (Indian coral tree)}

Chemical constituents: Alkaloids, flavonoids, triterpenoids, lectin, erythinine, hydrocyanic acid, galic acid, hydroxycinnamic acid ${ }^{[28,29,30]}$

1. Alcoholic extract of C.varigata.L leaves was evaluated by utertropic assay in 17 days old pre pubertal female rats and was chromatographically processed for compound isolation. In this treatment increased the absoluble and normalized uterine weight, uterine diameter, endothelial thickness, luminal epithelial cell height, diameter, ovary and number of primary and secondary ovarian follicles relative to vehicle control. ${ }^{[31]}$

Aloe vera. L. (Aloe):

Chemical constituents: Lignin, saponin, salicyclic acid, amino acid, isoleucine, lysine, methionine, phenylalanine, therionine, valine, tryptophan, aleruine, cysteine, glutamic acid, glycine, aspartic acid. ${ }^{[32,33]}$

1. A. vera is a suitable plant for developing antifertility drug. It is recommended for working out and should be experimented for antifertility program. $^{[34]}$

2. A. vera can be used as a contraceptive drug that can increase the estrogen level due to its phytoestrogen components such as $\beta$-sitosterol and without deterious effects on the other vital organs however it is use to be restricted with women suffering from low calcium level as well as osteoporosis. $^{[35]}$

3. The results obtained in this study different amounts of A. vera hydro-alcohol extract cause an increase in estrogen hormone in female rats. It appears that use of this plant could have positive effects on the process of fertility. ${ }^{[36]}$

Bauhinia racemosa. Lam (Bidi leaf tree):

Chemical constituents: Methyldibenzoxepin,

flavenolglycoside, triterpene, saponin, phenanthroquinone, flavonoids. ${ }^{[37,38]}$

1. In vivo investigation revealed that ethanol extract at dose of $200 \mathrm{mg} / \mathrm{kg}$ and $400 \mathrm{mg} / \mathrm{kg}$ shows significant increase in uterine wet weight and uterine weight ratio respectively in albino rats. It was observed that ethanol extract of B.racemosa produced significant estrogenic activity. ${ }^{[39]}$

\section{Asparacusracemosus. Willd. (Shatavari):}

Chemical constituents: Essential oil, asparagine, arginine, tyrosine, flavonoids, resin, tannin, steroidal glycoside(asparagosides), bitter glycoside, vit A,B,B1,B2,C,E,Mg,P,Ca,Fe and folic acid. ${ }^{[40,41]}$

1. Asparagus stimulant of endometrium and ovarian tissue regulating menstruation and ovulation, balance hormonal level,(TSH, FSH, LH, Estrogen) and improve conception rate in women. $^{\text {[42] }}$

2. A. racemosus extract increase in uterine weight and uterine glycogen without altering serum estrogen, progesterone levels in immature rats as against ovariectomized rats used as control. This study indicates that the phytoestrogen performs its function by binding directly to the estrogen receptor without enhancing the endogenous estrogen level. ${ }^{[43]}$

3. A. racemosusmethanolic extract is more potent in protecting the animals from osteoporosis the aqueous extract. All of their effects observed in this study are similar to estrogen treatment. Hence A.racemosus shall be considered as safe and effective antiosteoporosis in the treatment of postmenopausal condition. ${ }^{[4]}$

Nigella sative. L. (Black caraway):

Chemical constituents: Arachidonic, linoleic, linolenic, oleic acid, almitoleic, palmitic acid, stearic and myristic acid, $\beta$ sitosterol, cycloeucalenol, cycloartenol, sterol esters, sterol glycosides, thymoquinone, thymohydroquinone, thymol, carvacrol,P-cymene. ${ }^{[45]}$

1. N. sativa by giving different dose 300,600 $\& 1200 \mathrm{mg} / \mathrm{kg}$ respectively to overiectomized rat to observed low dose of $300 \mathrm{mg} / \mathrm{kg}$ of N. sativa show occurrence of vaginal cornified and nucleated 
epithelial cell which can be helpful in managing post menopausal symptoms as alternative for hormone replacement therapy. ${ }^{[46]}$

2. Low dose N. sativa methanol extract and linoleic acid had prominent estrogenic like effect which were significantly different from there of control group in different experiments. ${ }^{[4]}$

3. The ethanol extract of seeds showed antifertility effect in male rats that is probably due to inheritent estrogenic activity. ${ }^{[48]}$

Punicagranatum. L. (Pomegranate):

Chemical constituents: Polyphenol, flavonoids, anthocyanins, hydrolysable lipid. ${ }^{[49]}$

1. On line biochemical detection coupled to mass spectrometry was applied to rapidly profile the estrogenic activity in the pomegranate peel extract. ${ }^{[50]}$

2. The study suggest that the peel of P. granatum possess potent estrogenic activity in ovariectomized rat and substantiate the ethnic use in treatment of post-menopausal osteoporosis. ${ }^{[51]}$

Saracaasoca. Willd. (Ashoka tree):

Chemical constituents: Tannin, flavonoids, phytosterol, alexone, esters, anthocyanin, fattyacid, carbohydrates. ${ }^{[52]}$

1. The three doses administered to ovariectomized rats treatment with high dose was found to be more efficacious when compared with ovariectomized rats. The finding of this study firmly support the estrogenic potency of ethonolic extract of S.asoca which may be the reason of phytoestrogen. ${ }^{[53]}$

2. Treatment with S. asoca reduced the thickening of two to four layer and the serum estrogen level diminished significantly to compared to rats administered with estrogen alone. ${ }^{[54]}$

Caricapapaya. L. (Papaya):

Chemical constituents: Phytate, flavonoids, protein, carbohydrate, calcium, $\mathrm{Mg}, \mathrm{Fe}$ and $\beta$-carotene. ${ }^{[55]}$

1. C. papaya leaf contains flavonoid quercetin, which exhibits estrogenic effect. Based on the study the treatment of papaya leaf extract (PLE) increase the number of mammary lobules and uterine weight as well as estrogen dose. In summary PLE can be developed as a source of phytoestrogen. ${ }^{[56]}$

Glycine max. L. (Soya bean):

Chemical constituents: Carbamate, lupeone, coumesterol, apigenin, stigmosterol, $\beta$-sitosterol,
B-daucosterol. ${ }^{[57]}$

1. 11g soya contains $2.4 \mathrm{mg}$ phytoestrogens which is strongly estrogenic through it is a nonsteroidal plant product. It is a safe alternative to hormonal therapy. ${ }^{[58]}$

Cissusquadrangularis. L. (Devil back bone):

Chemical constituents: potassium, calcium, zinc, sodium, iron, copper, calcium oxalate, $\mathrm{Mg}$, resveratrol, piceatannol, pallidol, phenol, tannin, carotene. ${ }^{[59]}$

1. Friedelin rich fraction showed estrogenic activity as indicated by vaginal cornification increase in uterine weight and rise in serum estrogen. ${ }^{[60]}$

\section{Bambusaarundinacea Willd. (Bamboo):}

Chemical constituents: Oxalic acid, benzoic acid, arginine, cysteine, histidine, isoleusine, leucine, methionine, phenyl alanine, therionine, valine, tyrosine, niacin, riboflavin, thamin, glutaline, choline, nuclease, proteolytic enzyme. ${ }^{[61]}$

1. Estrogenic activity of the hydro alcoholic extract of B.aurinacaealeaves (HEBA) infemalewister râts. It was observed that HEBA possess significant estrogenic activity at $400 \mathrm{mg} / \mathrm{kg} .{ }^{[62]}$

\section{CONCLUSION:}

Only few scientific studies on plants are demonstrated its effect on sex hormones included that it may be useful as a contraceptive especially in preventing the transmission of HIV. Family planning has been prompted through several methods of contraception, but due to adverse effect produced by synthetic steroidal contraceptive attention has now been focused in indigenous plants for their possible contraceptive effects.

\section{REFERENCES:}

1. Muniramomin, nigella sativa blessed seed, International Journal of Research in Phytochemistry \& Pharmacology, 2013, Pg no 7884.

2. V. G. Padubidri, S. N Daftary, Shaw's Textbook of gynecology, $16^{\text {th }}$ edition $2015, \quad$ pg no $65-$ 73

3. Supernipinchearukul, Morindacitrufolia has very weak estrogenic activity in vivo, Thai Journal of Physiological Science vol17, April 2014, pg no 22-26.

4. Asieshojaii, Review of Pharmacological properties and chemical constituents of 
pimminellaanisum, ISRN pharmaceutics, 2012 July 16.

5. Mehmet musaozcan, Chemical composition and antifungal effect of anise (piminellaanism) fruit oil at ripening stage, Annals of microbiology 2006, Vol 56, pg no 353-358.

6. Marisa debo, Assesment report on pimpinellaanisum. Laethroleum, European medical agency, Nov 12, 2013.

7. Marisa debo, Assesment report on pimpinellaanisum. L, European medicines agency evaluation of medicines for human care, $10 \mathrm{aug}$, 2006.

8. Albert puleo, Anise as estrogenic agents, J. ethnopharmacol 19809,pg no 337-344.

9. Khaled mohammed, Approach to pharmacological and clinical application of anisiaetheroleum, Asian pacific journal of tropical biomedicine, $12 \mathrm{Nov}$ 2014.

10. Fatemannahidi, The study on the effect of p.anisum on relief and recurrence of menopausal hot flashes, Iran J. pharm res 2012, autumn, pg no 1079-1085.

11. Nurhayettabanca, Estrogenic activity of isolated compounds and essential oils of pimpinella species from turkey evaluated using a recabinant yeast screen, Article. M. Plantamedica, Sep 2004, pg no 728-35.

12. Kavitatyagi, Study of phytochemical constituents of Ricinuscommunis.L under the influence of industrial effluent, Journal of pharmacy research, Vol 6, Aug 2013,870-73.

13. Paulo R. Riberio, Chemical constituents of the oil seed crop ricinuscommunis and their pharmacological activites:A review, Industrial crops and products, Vol 91, 30 nov 2016, pg no 358-376.

14. Manojkumar, A review on p[hytochemical constituents and pharmacological activities of ricinuscommunis. L plant, international Journal of pharmacognosy and phytochemical research, 2017, pg no 466-472.

15. Mapreetrama, ricinuscommunis.l A review, International journal of pharm tech.research,Vol4, oct -Dec 2012, pg no 1706-1711.

16. Murtala, Effect of administration of aqueous suspension of ricinuscommunis seeds on serum estrogen and progesterone in female albino rats, Journal of natural science research, Vol5,2015,pg no: 2224-3186.

17. Shakira adenolesalani, Oral ricinuscommunis oil exposure to different stages of pregnancy impared hormonal lipid profile and histopathology of reproductive organs in wister rats, Journal of medicinal plants research,Vol 8, Nov 2014,12891298.

18. Assharoshan, Phytochemical constituents pharmacological activities and medicinal uses through the millennia of glycyrrhizaglabra. L:A review, International research journal of pharmacy, 2012.

19. Varshasharma, Glycyrrhizaglabra: chemistry and pharmacological activity, Sweeteners 5 Jan 2018, pg no;87-100.

20. Suveipoh. M, Estrogenicity of glabridin inishikana cells, Journal pone,2015 mar 27.

21. Somjen. D, Estrogenic activity of glabridin and glabrene from licorice roots on humans osteoblast and prepubertal rat skeletal tissues, j. steroid biochem boil, 2004, aug9, 241-6.

22. Simoms. R, Agonistic and antagonistic estrogens in licorice root, Anal bioanalchem 2011, jul ,pg no;305-313.

23. Sanjen. D, Estrogen like activity of licorice root constituents glabridine and glabrene in vascular tissue in vitro and in vivo, $\mathrm{J}$. steriodbiochemmol.biol, 2004, july,pg no;147155.

24. Lavanya. k, Musa paradisiaca- Areview on phytochemistry and pharamacology, World journal of pharmaceutical and medical research, 2016,pg no:163-173.

25. Azizahmohmood, Phytovhemicals constituents and antioxidant activity in musaparadisiaca flower, Research gate Dec 2011.

26. Paul. C. Onyenekwe, phytochemical screening and effect of musaparadisiaca stem extrude on rat heamatology, Current research journal of biological science,2013,26-19.

27. Priyankssoni, Antiovulatory and estrogenic activity of stem of musaparadisiaca in female albino rat, Journal of applied pharmaceutical science, Vol3, aug 2013,102-106. 
28. A. kumar, Erythrina variegate 1. a review on morphology phytochemistry and pharmacological aspects, Pharmacognosy reviews, 2010 jul-dec,pg no; $147-152$.

29. Lahari. K, A novel review on Erythrinavarigata, International research journal of pharmacy, 2015.

30. Suriyavathanamuthukrishnan, Phytochemical profile of erythrinavarigata by using high performance liquid chromatography and gas chromatography-mass spectroscopy analysis, Journal of acupuncture and meridian studies, Vol 9, Aug 2016, pg no;207-212.

31. K. Mangathayora, Estrogenic effect of erythrinavaregata. L in prepubertal female rats, Indian journal of natural products and researchs, Vol 5,sep 2014,pg no 223-227.

32. Amar surjushe, Aloe veraashort review, Indian journal of dermatology 2008,163-166.

33. Dr. Christopher, Herbal legacy, The benefits of the use of aloe vera in herbal preparation.

34. Sunilkumarshab, Antifertility activity of ethonolic and aquous extracts of aloe vera on female wister rat risky approaches of herbal contraceptive, Journal of pharmaceutical science and research, Vol 8,2016.

35. Emanhelal, Studies on the use of aloe vera extract as a contraceptive in female rats, Reaearchgate, july 2015.

36. Proorfarid. M, The effects of aloe vera on progesterone, estrogen and gonotropin in female rat, Journal of jahram university of medical sciences, Vol 10,2013.

37. Anuraykumar, Plant profile, phytochemistry and pharmacology of bauhinia varigata.L.na overview, International journal of Pharmacocnacy,2017.

38. G. K. Sharanabasappa, phytochemical studies on bauhinia racemosa. Lam bauhinia purpurea 1 . and hardwickia binate roxb, E.Journal of chemistry, Vol 4, Jan 2007,21-31.

39. Gautan P. vadneve, Estrogenic activity of bauhinia racemosa extract in female albino rats an investigational study, Phcogj Nov-dec 2014, Vol 6.

40. J. S. Negi, Chemical constituents of asparagus, Pharmacognosy review 2010 Jul, 215-220.

41. Rakesh J. Joshi, asparacusracemosus (shatavari) phytoconstituents and medicinal impotance, future source of economy by cultivation in utrakand; A review, International journal of herbal medicine.2016,18-21.

42. A. k. Dang, Use of shatavari as a galatonic and therapeutic herb; A review, Agri.rev, 2008.

43. Komalsharma, Asparagus racemosus, A versatile female tonic, International journal of pharmaceutical \& biological archieves, 2011, pg no; 855-863.

44. H. R. Chitme, Effect of asparagus racemosuswilld root extract on overiectomized rats, the open products journal, 2009,pg no; 16-23.

45. Fatemehforouzanfar, black cumin and its constituents (thymoquinene) a review on antimicrobial effects, Iranian journal of basic medical science,2014, pg no;929-938.

46. Muniramomin, Nigella sativa blessed seed, International journal of research in phytochemistry\&pharmacology,2013,pg no;78-84.

47. Saadatparhiizkar, Effect of Nigella sative on reproductive system in experimental menopause rat model, Avienna journal of phytomedicine, Vol 6,jan-feb 2016,95-103.

48. Padma. M. paarakh, Nigella sativa L A comprehensive review, Indian journal of natural products and resorced, Dec 2010, pg no; 409-429.

49. C. V. S. Praksah, Bioactive chemical constituents from pomegrantate juice seed and peel; A review, Research gate, Jan 2012.

50. Van Elswijk, Rapid direplication of estrogenic compounds in pomegranate using on line biochemical detection coupled to mass spectrometry, phytochemistry,2004 jan,233-241.

51. Swahasatpathy, Estrogenic activity of punicagranatum. L peel extract, Asian pacific journal of reproduction, 2013, pg no;19-24.

52. N. S. Ashokrae, An overview of saracaindica chemistry and pharmacological profile, Research gate. Jan 2006, pg no; 277-281.

53. Gowriswara, Activity based evaluation of a traditional ayurvedic medicinal plants saracaasocawilld flower as estrogenic agents using ovarectamized rat model, Journal of ethanopharmacology, Vol 195, Jan 2017, pg no;324-333.

54. Shahid A P, Effect of saracaasoca on estradiol induced keratinizing metaplasia in rat uterus, J. 
Basic Clinphysiol, Pharmacol 2015, sep 26,pg no;509-515.

55. Okpeoche, Chemical constituents and nutrient composition of carica papaya and vernonia leaf extract, Journal of complementary and alternative medical reseach, Vol 2, pg no;2456-6276.

56. Raisatummisasugiyanto, Ethanolic extract of papaya leaf exhibits estrogenic effect in vivo and in situ, Indonesian journal of cancer chemoprevention, 2012,pg no;385-391.

57. M. Zhang, Chemical constituents from pods of glycine max, Chinese traditional and herbal drugs, Feb 2015,pg no;344-347.

58. Boue S M, Evaluation of the estrogenic effect of legume extract containg phytoestrogen. J. Agric. Food. Chem 2003, April 9,pg no; 2193-2199.
59. Monokeshkumarsen, A review on phytochemical and pharmacological aspects of cissusquadrangularis, International journal of green pharmacy, 2012, pg no;169-173.

60. Urmde. S. Aswar, Estrogenic activity of modelin rich fraction separated from cissusquadrangularis and its effects in female sexual function, Pharmacognocy research, 2010.

61. Rathodjaimik. D, phytopharmacological properties of bambusaarundinaceae as a potential medicinal tree; An overview, Journal of applied pharmaceutical science,2011.

62. Talhajawaid, Estrogenic activity of a hydro alcoholic extract of bambusaauridinacae leaves on female wister rat, J. Adv. Pharm Technol Res, 2015, Jan-mar, pg no;19-24

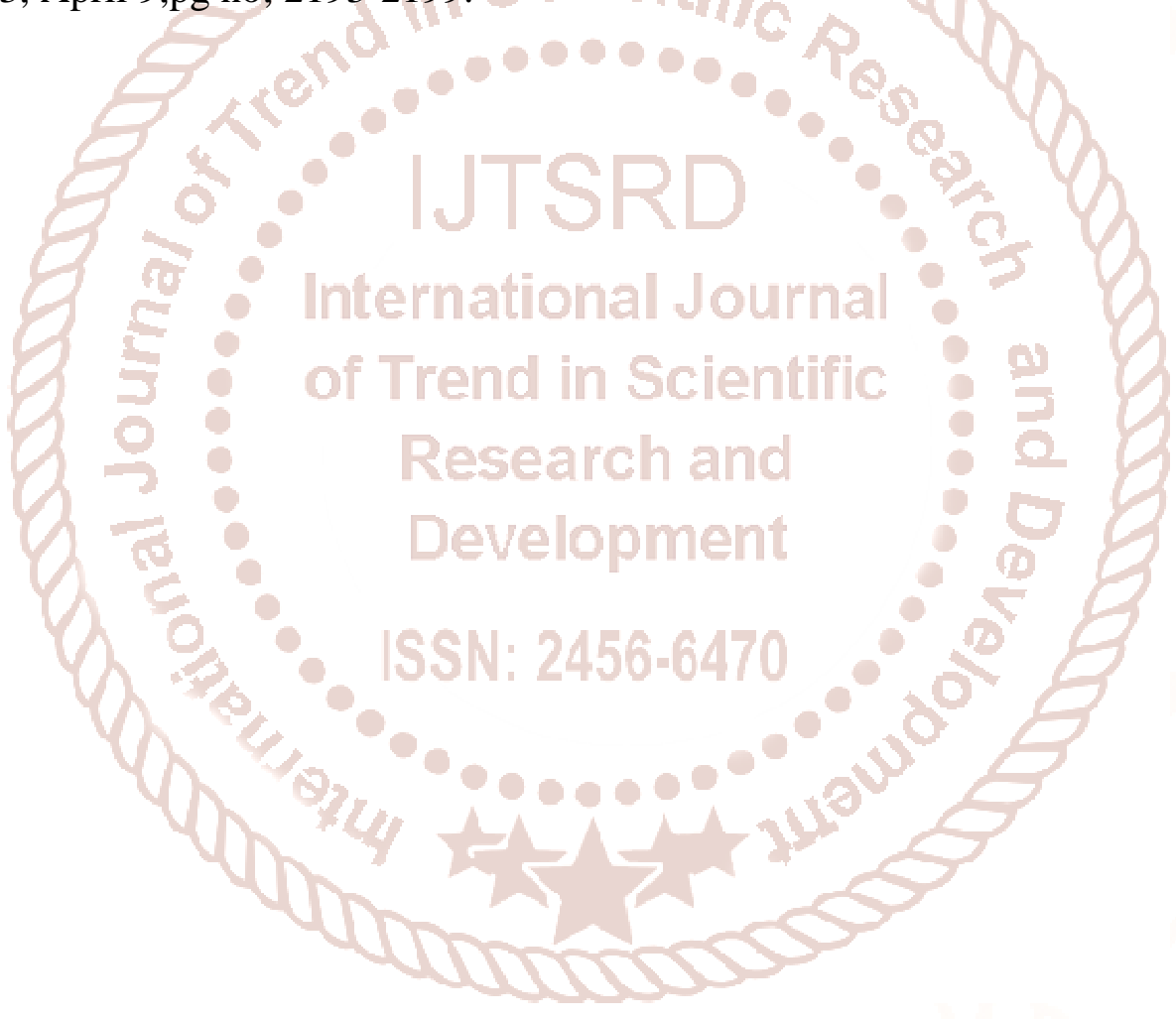

